\title{
The Development of International Tourism in Myanmar
}

\author{
Li Zhifei* \\ International Cooperation and Exchange Office \\ Yunnan University of Finance and Economics \\ Kunming, Yunnan, China \\ lizhifei1115@126.com
}

\author{
Li Hongmin \\ International Cooperation and Exchange Office \\ Yunnan University of Finance and Economics \\ Kunming, Yunnan, China \\ 99663759@qq.com
}

\begin{abstract}
Myanmar's domestic and foreign policies have undergone dramatic changes since 2010. With the successful holding of the election in Myanmar, the new civilian government is accelerating its economic and democratic reforms. And the explosive development of tourism in Myanmar has earned more and more international interest. Even though the tourism in Myanmar has shown a great potential and already became a significant source of revenue, to achieve the sustainable development, the county still faces various hardships and challenges. This paper tries to use the SWOT module to analyze the main challenges and developable prospect of international tourism in Myanmar, in order to rise some ideas on improving the development of Myanmar's tourism industry cluster.
\end{abstract}

Keywords-Myanmar; reform; international tourism; investment

\section{THE DEVELOPMENT OF INTERNATIONAL TOURISM IN MYANMAR}

As a beautiful country with a long history, diverse cultural resources and natural wildlife, Myanmar has exceptional advantages to develop tourism industry.

\section{A. Diverse and potential touristy resources}

Initially, covering an area of 676, 577sq. km., Myanmar ranks as the second largest country in the ASEAN, and has an abundance of natural tourism assets. Its northern parts closely connect with the snow-capped Greater Himalaya, with pristine forests cover the Arakan Mountain and the Shan Hills. While southern borders of Myanmar extend to the Indian Ocean, with 2,832 km of coastline and beautiful seaside resorts [9]. Besides, in Yangon, the picturesque natural highland lake, Inlet Lake, attracts thousands of travelers every year. At December 28, 2011, CNN named Myanmar as one of the world's best tourist destinations in 2012, the report claimed that Myanmar was a pure land where had the most kindhearted people [4].

Expect for the lush green of tropical forest, a golden, sunburnt yellow also shines brightly throughout the nation. As one of the most devout Buddhist countries in the world, Myanmar is known as Land of golden pagoda with outstanding examples of religious and vernacular architectures From the smallest village to the bigger urban centers, thousands of graceful old pagodas and temples can be found everywhere. The Shwedagon Pagoda is the most popular and well-known pagoda in Myanmar, which has already become one of the main tourist destinations in Yangon. Besides, in Bagan, tourists can find more than 2,000 pagodas, which have a history of nearly 700 years [3]. Such a large-scale ancient pagodas is extremely rare not only in Southeast Asia, but also in the world.

Last but not the least, Myanmar's history of former kingdoms, the colonial period as well as World War II is a valuable asset for the development of a prospective tourism. And the diverse and exotic traditions and customs from ethnic minorities also become an attraction of Myanmar's tourism.

\section{B. New government and changes of strategies}

With the successful holding of the election in 2010 and the release of NLD leader Aung San Suu Kyi, new civilian government came to power on April 1, 2011, Myanmar facing an unprecedented change. Excepting release of some political prisoners, implement of open-door policy and relaxation of press, Aung San Suu Kyi and her party National League for Democracy also expressed the opinion that international tourism to Myanmar should be encouraged. In order to build the tourism as the major pillar of economic development, new government launched several promotive actions:

First, extending expiration date of visa-on-arrival, and simplifying the approval procedure. Since 1988, because of the political circumstance, entry requirement for tourists has been progressively streamlined in Myanmar. And this situation had lasted for a very long time. However, after 1 June, 2012, foreign tourists can apply for visa-on-arrival at Yangon and Mandalay international airports with a passport valid for at least 6 months from the date of arrival and are also granted a stay of 28 days. The government also claimed to streamline and simplify the approval procedure of visa and introduce an e-visa system in 2013 and fully conduct the ASEAN Framework Agreement on visa Exemption in the future.

Second, rejoining UN World Tourism Organization, and conducting international cooperation. To enhance the internationalization of tourism, in March 2012, Myanmar government decided to rejoin the UNWTO and World Travel

*Corresponding author 
\& Tourism Council (WTTC). In 2013, the Ministry of Hotels and Tourism in Myanmar and the government of Norway have launched cooperation with the responsible stakeholders as well as Asian Development Bank (ADB), and published the Myanmar Tourism Master Plan. The aim of this Master Plan is to amplify tourism's contribution to domestic employment and revenue increase while guaranteeing the social and economic benefits of tourism are distributed equitably. It defined a promising vision, leading principles as well as strategic programs in the form of a long-term implementation framework (2013-2020). The government believed that the Master Plan will become a development milestone for the sustainable and integrated improvement of Myanmar's international tourism [7].

Last but not the least, promoting the foreign investment in tourism. Since the early 1990s, the government in Myanmar has strengthened the control and management of national tourism resources. According to the Myanmar Tourism Law, the government abolished the old policy, which only allowed the state-run departments to operate tourism. While the new government came to the stage in 2012 , private enterprises and foreign investors, who hold licenses, can also operate businesses of tourism industry including hotel business, tourist transport business, tour guide business and so on. Because of the looser policy, tourism has now become the fifth-largest source of foreign direct investment in Myanmar, which, according to government statistics, in 2015, amounts to nearly US\$ 2678.380 million divided between 48 projects. Singapore is the largest investor, followed by Vietnam, Thailand, Hong Kong and Japan [9].

\section{Current situation of international tourism in Myanmar}

Five years have passed, from 2011 to 2015, the international tourism in Myanmar began to revive quickly. The visitor numbers and the income of tourism foreign exchange have showed startling growth year on year.

Recently, Myanmar's newly released tourism statistics for 2015 show an exciting record. In 2012, tourist arrivals surpassed the one million mark for the first time [8], while the number rises to $4,681,020$ in 2015 , facing a surprising increase of nearly 4 times, which reaching the highest record ever in Myanmar's tourism industry. In the 2013, the Tourist Master Plan 2013-2020 in Myanmar was launched by the national government, targeting 3.01 million in 2015, which number has already been exceeded in 2014 .

In 2015, Asian countries still occupied the major origins of Myanmar's visitors, Asian countries' visitors consisted $72.10 \%$ of the total number, followed by West European visitors with $16.08 \%$, while North America and Oceania ranked of third and fourth with $6.44 \%$ and $2.73 \%$ respectively, least of the visitors came from Middle East and Africa [9]. When talking about the individual countries, Thailand, China and Japan occupied the top three of the origin of visitors.

According to the statistics from Ministry of Hotels and Tourism of Myanmar, the international tourism income has grown rapidly. During the early stage of opening up, in 2011 and 2012, the total tourism income in Myanmar was only US\$ 319 million and US\$ 534 million respectively [8], while this number skyrocketed to US\$ 2122 million in 2015 the average expenditure of per person per day reached US\$171, and average length of stay was 9 days.

\section{THE CHALlENGES OF INTERNATIONAL TOURISM IN MYANMAR}

Obviously, international tourism has already become the national priority in Myanmar, it not only accelerates poverty reduction and economic growth, but also contributes to national reconciliation and the democratization process at the same time. However, there are still various hardships and challenges which constraint the sustainable development of international tourism in Myanmar.

\section{A. Shortage of professional services during the peak season}

During the peak season of tourism, various challenges arising with the flow of the highly concentrated travelers. The biggest problem is lack of enough hotels. Until 2015, Myanmar has 1279 registered hotels with 49,946 rooms. The majority of hotels are in Yangon, Mandalay and Bagan, with number of 324, 168 and 78 respectively [8]. However, from October to February every year, these major cities are still struggling to meet demand. As a result of customers' excessive demand for hotels, significant price increase and power outage frequently happen. Some experts predicted it's an issue that's not going away any time soon -- the major hotel shortage is expected to continue for the next five to 10 years [5].

Nowadays, there is an increasing number of travel agency and tour guide in Myanmar. Myanmar now has 1,946 registered travel agencies and 5,630 licensed tour guides, including 2,349 English-speaking guides and hundreds of guides who speaking Japanese, Thai, Chinese, French or German [9]. While there is still a shortage of professional tour guides, and the availability of tourist vehicles become limited. Abundant travelers also need better public services such as the collection and treatment of solid waste and wastewater. And with this expanding of international tourism, some environmentalists worry that because of the insufficient policies and distempered system of environmental protection in Myanmar, negative influence on historical heritages and natural resources may be exacerbated.

\section{B. Backward infrastructures}

According to a report from the World Bank, Myanmar has the weakest transportation and infrastructure in Southeastern Asia. Although Myanmar has diverse natural and cultural resources from north to south, there are only 3 international airports in Yangon, Mandalay and Naypyidaw, which have parking apron for 747-class aircraft. As for road infrastructures, there are totally $130,000 \mathrm{~km}$ road in Myanmar including only around $400 \mathrm{~km}$ highway [13]. Expect for the three major highways connecting Yangon, Mandatory and Naypyidaw, many highways in Myanmar are in poor condition with bumps and holes. Most of the roads have no or very few maintenance and suffer extensive degradation. All these factors make traveling around Myanmar very difficult and inefficiency, even inaccessible in some areas, for tourists. 


\section{Ethnic conflicts and unstable environment}

Moreover, the social environment in Myanmar is till unstable. Myanmar is one of the countries with serious ethnic problems in the Southeast Asia, and ethnic conflict always poses a hindrance to Myanmar's development since independence. Even today, the minority groups like Karen, Shan and Kokang are still fighting against the government in the east of the country. Besides, the ethnic conflicts of Rohingya also become more dramatic these years. Foreign tourists always get an unstable and insecure impression on Myanmar because of the ethnic conflict, and many areas occupied by minorities are still can't be opened to tourists. Besides, some border regions in Myanmar are notorious for drug trafficking, for example, the Golden Triangle. Although Myanmar government have cooperated with the UN' Office on Drugs and Crime to crack down on drug trafficking and transnational crime for many years, the drug problem is still a big threat to social stability in Myanmar.

\section{Lack of practical regulations and legislations}

New government has expressed the opinion that tourism in Myanmar should be encouraged, and the Myanmar Responsible Tourism Policy was launched to prevent the potential unsustainable tourism growth and negative impacts relating to the environment, culture and society [8]. However, the government still using the old Hotles and Tourism Law, which was launched in early 1990s. This law made in a special period, during which most of the western countries had imposed harsh sanctions and blockade to Myanmar. While times have changed, many clauses in the law have become impractical in the new era. For instance, there is no protection clauses for tourists or channels for complaints in the law, not to mention the scientific recycling and disposal system of garbage, or effective training for employees. If the government continues to follow this law, it may cause dilemmas and even disputes in real situations.

\section{THE PROSPECT OF INTERNATIONAL TOURISM IN MYANMAR}

While Myanmar still need to address different challenges, the potential for further expansion of international tourism remains huge.

\section{A. Closer tourism cooperation with neighboring countries}

Since the new civilian government is speeding up its democratic and economic reforms and actively integrating into the regional and international cooperations, neighboring countries, especially ASEAN countries start to conduct closer collaborations with Myanmar. In 2010, member states,including Myanmar, signed the ASEAN Tourism Strategic Plan 2011-2015 to promote the tourism growth in the community and build ASEAN as a strong competitor within the global tourism environment. One specific goal of this strategy is to achieve visa exemption in member countries as soon as possible. Although this goal has not been fully accomplished yet, Myanmar has signed visa exemption with more and more ASEAN countries including Cambodia, Laos,
Thailand, Vietnam, Indonesia, Brunei, Singapore and and the Philippines [12].

What's more, in recent years, neighboring countries like China also launched various tourism cooperation with ASEAN The Federation of ASEAN Travel Association (FATA) tries to promote member states to waive entry visa requirements for travelers among from China, Japan and South Korea, in order to boost the regional tourism industry. If all these actions could be implemented quickly, not only would be good for the tourism industry, it would also improve Myanmar's international standing.

\section{B. Increasing foreign investment and international aids}

In December 2011, U.S Secretary of State Hillary Clinton finished her historic visit to Myanmar. Only a year after, in November 2012, U.S President Barack Obama became the first American president to visit Myanmar. After that, there was a bigger influx of foreign tourists, especially from western countries, into Myanmar, and the demand of hotel also greatly increased. Therefore, many foreign investors pay much attention to hotel business in Myanmar. According to the government's figure, there are 794 foreign investors who have the hotel investment licenses [9], while the excessive demand for this permit still can't be satisfied. Various high profile foreign projects, such as a luxurious Hotel in Yangon invested by Hilton enterprise and a Novotel-branded development by Accor Hotels, have been completed in 2014, bolstering Myanmar's paltry supply of international-standard hotel rooms and effectively addressing the urgent need of hotels during the peak season.

Except for the business investment, because of the process of opening up, many international organizations also extend the olive branch and provide more aids to Myanmar. For example, since 2013, Asian Development Bank (ADB) has been focused on supporting the improvement of infrastructure in Myanmar, particularly its road network, by using the public-private partnerships (PPP) module. Currently, ADB has conducting the Rural Roads and Access, Power Network Development, Greater Mekong Subregion Highway and other relevant projects in Myanmar [2]. According to ADB, all these projects could not only approve better infrastructures to tourists, but will also help Myanmar grow the economy, create jobs and improve living conditions of local people.

\section{Development of air services}

Nowadays, Myanmar government also realizes that transportation infrastructure play a crucial role in development of tourism. Therefore, the Ministry of Transportation has launched a series of actions to develop Myanmar's transportation, especially air services. To supply a better air service to international tourists, the Hanthawaddy airport, which $80 \mathrm{~km}$ from Yangon, began its construction in 2016 and will be completed by 2020 , and by that time, it will become the fourth international airport in Myanmar [11]. In 2015, apart from seven national airlines (i.e. Air Bagan, Air KBZ, Air Mandalay, Asian Wings, Golden Myanmar, Myanmar Airways and Yangon Airways), international airlines, such as AirChina, China Southern Airlines, Malaysian Airline System, Thai Airways International, Silk Air and Jet Star, have also 
opened international routes arriving in Myanmar. And according to the government's plan, to the end of 2017, Myanmar's international airports will have a total operating capacity of at least 20 million passengers per year, which will be sufficient to meet expected demand.

\section{CONCLUSION}

According to the report from the World Travel and Tourism Council, in 2014, the direct contribution from travel and tourism to Myanmar's GDP stood at MMK1, 347.4bn, or $2.2 \%$ of GDP. The total contribution to GDP, which takes into account the wider effects from investment, the supply chain and income effect, reached MMK3, 025.6bn, or 4.8\% of GDP, and is forecast to rise by $6.7 \%$ in 2015 . Although the newest 2016 report has not be published yet, if Myanmar achieves $50 \%$ growth in 2015 , as targeted, the revenue figure is likely to be a lot higher [14].

Based on previous discussions people can tell, although the development of international tourism in Myanmar starts very late and facing various problems, it still has a promising market. If the government can make more specific regulations and legislations, promote the regional and even international cooperation to improve the infrastructures and professional services, and ease conflicts among different ethnic groups to build a more stable environment, the international tourism in Myanmar will have a bright future.

\section{ACKNOWLEDGMENT}

I would like to express my deepest gratitude to all those who have given me their generous helps, commitment and enthusiasm, which have been the major driving force to complete the current paper.

\section{REFERENCES}

[1] Asian Development Bank, "Technical assistance completion report about Myanmar tourism master plan," 2013.

[2] Asian Development Bank. https://www.adb.org/countries/myanmar/ main.

[3] C. Michae, and J.P. Stephen, "Tourism in South and Southeast Asia," Routledge, 2012, pp. 141-168.

[4] CNN Travel, Top places to visit in 2012 http://travel.cnn.com/explorations/escape/best-places-visit-2012-776891/

[5] CNN Travel, Myanmar hit by severe hotel shortage. http://travel.cnn.com/hotel-shortage-myanmar-963446/

[6] J. C. Henderson, "The politics of tourism in Myanmar. Current Issues in tourism," Current Issues in Tourism, 2003, 6(2), pp. 97-118.

[7] "Ministry of Hotels and Tourism of Myanmar," Myanmar tourism master plan 2013-2020, 2013.

[8] "Ministry of Hotels and Tourism of Myanmar," Republic of the union of Myanmar responsible tourism policy, 2012.

[9] "Ministry of Hotels and Tourism of Myanmar," Myanmar tourism statistics, 2015.

[10] Michael J.G. Parnwell, "Tourism, globalization and critical security in Myanmar and Thailand," Singapore Journal of Tropical Geography, vol. 19, 2010, pp. 212-231.

[11] "Hanthawaddy Airport Construction to Start in 2016," Myanmar Business Today. http://www.mmbiztoday.com/articles/hanthawaddyairport-construction-start-2016.

[12] "Visa exemption signed with Singapore," Myanmar Times. http://www.mmtimes.com/index.php/national-news/nay-pyi-taw/20724visa-exemption-signed-with-singapore.html.

[13] "Road Transport in Myanmar-Highway," Today in Myanmar. http://www.myanmar2day.com/myanmar-information/2009/04/roadtransport-myanmar-burma-highway/

[14] “Travel and Tourism Economic Impact2015----Myanma," World Travel and Tourism Council. 